\title{
ПІСЛЯДИПЛОМНА ОСВІТА ЛІКАРІВ: СУЧАСНІ СТРАТЕГІЇ ЛІКУВАННЯ ФІБРИЛЯЦІЇ ПЕРЕДСЕРДЬ
}

\author{
С. М. Маслій
}

Обласна клінічна лікарня, м. Рівне

\section{POST-GRADUATE EDUCATION OF DOCTORS: MODERN STRATEGIES OF TREATMENT OF ATRIAL FIBRILLATION}

S. M. Masliy

\author{
Regional Clinical Hospital, Rivne
}

\begin{abstract}
У статті наведено методологічні особливості сучасних підходів до лікування фібриляції передсердь. У розрізі “upstream”стратегії продемонстровано ефективність застосування блокатора рецепторів ангіотензину II олмесартану та біофлавоноїду кверцетину у комплексній терапії хворих на фібриляцію передсердь. Означено, що одним із основних чинників реалізації сучасних стратегій лікування повинна стати безперервна післядипломна освіта лікарів.

The article deals with the methodological features of the modern ways of treatment of atrial fibrillation. In the cut of "upstream"strategy efficiency of application of blokator receptors of angiotensin II Olmesartan and bioflavonoid Quercetin are shown in the complex therapy of patients with atrial fibrillation. It was set, that one of the basic factors of modern strategies realization of treatment must be continuous post-graduate education of doctors.
\end{abstract}

Вступ. Найбільш поширеним порушенням ритму в клінічній практиціє фібриляція передсердь (ФП) [1]. За останні 20 років частота випадків даної патології виросла на $66 \%$, а серед госпіталізованих хворих 3 порушеннями ритму 40 \% складають пацієнти із ФП [2]. Згідно з 5-літніми даними дослідження SPRINT, шпитальна летальність у хворих із ФП була в 1,6 раза більшою, а 1-річна і 5-річна летальність при пароксизмальній формі ФП виявилась у 2,4 i 1,7 раза вищою, ніж у хворих із синусним ритмом [3].

Згідно з рекомендаціями 2007 року [4], передбачено дві стратегіїі ведення хворих на ФП - стратегія контролю ритму і стратегія контролю частоти серцевих скорочень (ЧСС). Однак в умовах коморбідності ФП ефективність даних стратегій не завжди дає бажаний ефект, що нами описано раніше [5]. Тому тактика ведення хворих на ФП залишається однією із ключових проблем аритмології. Сьогодні у світі ініційована найновіша стратегія "upstream" терапії [1], яка передбачає сповільнення або припинення прогресування ФП як шляхом впливу на серцево-судинне захворювання, яке привело до порушення ритму, так і на саму ФП. Ця терапія включає інгібітори АПФ, блокатори рецепторів ангіотензину II (БРА), антагоністи альдостерону, статини, омега-3-поліненасичені жирні кислоти. На жаль, в умовах реальної клінічної практики як лікарі загальної практики, так і спеціалісти-кардіологи недостатньо ознайомлені з цією стратегію і не користуються іiі очевидними перевагами.

Основна частина. Мета нашого дослідження продемонструвати клініко-функціональну ефективність "upstream" стратегії на прикладі власного досвіду застосування, розробленого нами, комплексу лікування з включенням БРА олмесартану та біофлавоноїду кверцетину у хворих на ФП.

Для порівняльного дослідження різних методик лікування, з метою стандартизації груп відібрані пацієнти, у яких генез ФП найбільш вірогідно був пов'язаний з атеросклерозом вінцевих судин. Тому оцінювались вікові, статеві характеристики, ведучі фактори ризику атеросклерозу й коморбідні стани.

Усім пацієнтам за відсутності протипоказань призначали рекомендовану чинним протоколом стандартну терапію для контролю ритму - електричну або медикаментозну (пропафенон, кордарон) кардіоверсію 3 наступним тривалим вживанням кордарону, дронедарону, соталолу або бісопрололу; для контролю частоти серцевих скорочень - $\beta$-адреноблокатори (бісопролол), дигоксин. Супровідна терапія включала антиагреганти i антикоагулянти (аспірин, низькомолекулярні гепарини, варфарин). Пацієнти, які отримували стандартну терапію відповідно до протоколу, були включені до групи контролю (n=75).

(c) С. М. Маслій 
У групі дослідження (n=28) додатково до комплексної терапії призначався флавоноїд кверцетин (ЗАТ НВЦ “Борщагівський ХФЗ”) по 2 г тричі на день і ольмесартану медоксоміл (Кардосал ${ }^{\circledR}$ 20-40 мг/д, "Berlin-Chemie Menarini group", Німеччина).

Кардіопротекторні властивості кверцетину пов’язані з підвищенням енергетичного забезпечення кардіоміоцитів завдяки антиоксидантному впливу і поліпшенню кровообігу, що підтверджено експериментально [6]. Тому для підвищення ефективності електричної кардіоверсії, зменшення пошкоджуючого впливу електричної енергії на міокард та пролонгації стабільного ритму використано розчинну форму кверцетину - корвітин за добу до процедури і упродовж трьох діб після кардіоверсії з переходом на пероральну форму.

У процесі комплексної терапії усі дані моніторувались тричі: на стаціонарному етапі (1), під час візитів через 6-12 місяців (2 візит) і через 18-24 місяці (3 візит).

Критерієм ефективності контролю ритму вважали утримання стійкого синусового ритму упродовж періоду спостереження. Критерієм ефективності медикаментозного контролю ЧСС при перманентній ФП вважали середньодобову ЧСС не більше 80 уд./хв за даними Холтерівського моніторингу ЕКГ (ХМЕКГ) і відсутність епізодів понад 100 уд./хв у спокої та збільшення ЧСС не більше 120 уд./хв під час фізичного навантаження.

Використані клінічні, лабораторні, інструментальні дослідження та методики статистичної обробки даних, описані нами раніше [5].

У досліджуваній групі пацієнтів супутня артеріальна гіпертензія (АГ) виявлена у 83,33\%, а індекс маси міокарда перевищував нормальні значення в середньому на 10,00 \%. Крім цього в обстежених нами хворих спостерігали порушення скоротливої здатності міокарда переважно у вигляді діастолічної дисфункції у 68,25 \%. Загальна характеристика хворих на початковому етапі лікування представлена в таблиці 1.

Як видно, за віковим складом і статевою ознакою хворі групи були аутентичними. За основними ФР атеросклерозу у 1 групі отримано статистично вірогідну різницю в індексі маси тіла $(p=0,025)$, на перший погляд переважала частка хворих із супутньою АГ, ХОЗЛ, проте як за цими коморбідними станами, так і відсотком курців різниця виявилась статистично недостовірною. Метаболічні порушення у вигляді гіперурикемії, метаболічного синдрому та наявності цукрового діабету були притаманні для хворих, які були відібрані у групу комплексної терапії. У цю же групу попали пацієнти з перенесеним в анамнезі мозковим інсультом $(16,67 \%)$.

Таблиця 1. Загальна характеристика хворих, яким було призначено комплексне лікування (1 група) i 3 групи базисної терапії (2 група) $(\mathrm{M} \pm \mathrm{m})$

\begin{tabular}{|c|c|c|c|}
\hline Показник & 1 група, $\mathrm{n}=28$ & 2 група, $\mathrm{n}=75$ & $\mathrm{p}$ \\
\hline Вік, p. & $56,33 \pm 3,97$ & $50,27 \pm 3,19$ & нд \\
\hline Чоловіки, \% & 75,00 & 66,67 & нд \\
\hline Жінки, \% & 25,67 & 33,33 & нд \\
\hline 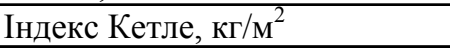 & $35,16 \pm 1,99$ & $27,73 \pm 1,75$ & 0,025 \\
\hline $\begin{array}{l}\text { Куріння, \% } \\
\text { пачко/роки }\end{array}$ & $\begin{array}{c}49,08 \\
15,71 \pm 3,39\end{array}$ & $\begin{array}{c}62,54 \\
19,10 \pm 6,71\end{array}$ & $\begin{array}{l}\text { нд } \\
\text { нд }\end{array}$ \\
\hline Артеріальна гіпертензія, \% & 83,33 & 66,67 & нд \\
\hline Тривалість анамнезу АГ, р. & $10,04 \pm 3,46$ & $8,24 \pm 2,11$ & нд \\
\hline Цукровий діабет, \% & 23,33 & 8,33 & 0,04 \\
\hline ХОЗЛ & 16,67 & 8,33 & нд \\
\hline $\begin{array}{l}\text { Гіперурикемія, \% } \\
\text { сечова кислота, ммоль/л }\end{array}$ & $\begin{array}{c}28,57 \\
428,50 \pm 35,10 \\
\end{array}$ & $\begin{array}{c}32,00 \\
435,20 \pm 33,30 \\
\end{array}$ & $\begin{array}{l}\text { нд } \\
\text { нд }\end{array}$ \\
\hline
\end{tabular}

Примітка. Нд - різниця показників недостовірна.

Зважаючи на значення порушень функціонального стану щитоподібної залози у розвитку ФП, важливим було зіставлення груп лікування за даною ознакою. За середніми показниками концентрації ТТГ, $\mathrm{T}_{3}$, $\mathrm{T}_{4}$ i антитиреоїдних антитіл достовірної різниці не виявлено. Морфологічні зміни за даними ультразвукового обстеження у вигляді зоба підтверджені в обох групах. Зокрема, об’єми перешийка, правої і лівої часток щитоподібної залози становили, відповідно, у 1 групі- $(0,50 \pm 0,03),(10,94 \pm 1,19) \mathrm{i}(10,39 \pm 1,32) \mathrm{cm}^{3}, \mathrm{y}$
2 групі - $(0,38 \pm 0,05),(13,34 \pm 2,72) \mathrm{i}(10,39 \pm 1,32) \mathrm{cm}^{3}$, $\mathrm{p}>0,05$. При дообстеженні у $16,67 \%$ хворих в обох групах виявлено субклінічний гіпотиреоз.

Класифікаційна структура хворих на ФП суттєво не різнилась, пароксизмальна форма ФП діагностована у 26,57 \% у 1 групі і у 24,11 \% у 2 групі, персистуюча, відповідно, - у 44,86 і у 50,67 \%, постійна -у 28,57 і $25,22 \%$. Симптомна ФП спостерігалась у 67,00 \% пацієнтів 1 групи і у 73,00 \% 2 групи, відповідно “німа” ФП - у 33,33 і 27,50 \%. 
За клінічними проявами у 1 і 2 групах домінували скарги на серцебиття, перебої в роботі серця, задишку і зниження толерантності до фізичного навантаження, відповідно, у 100 і $80 \%$; 67 і $60 \%$; 67 і $80 \%$; 50 i $25 \%$. За шкалою $\mathrm{CHADS}_{2}$ ризик тромбоемболічних ускладнень, розрахований на ініціальному етапі, вірогідно був вищим у хворих 1 групи і становив $(2,33 \pm 0,42)$ проти $(1,29 \pm 0,28)$ у 2 групі.

Вихідна середня ЧСС за даними ХМ ЕКГ у 1 групі становила $(98,33 \pm 7,92)$ уд./хв, у 2 групі $(104,00 \pm 12,88), \mathrm{p}>0,05$. Серцева недостатність відповідала II ФК NYHA у 16,67 \% досліджуваних з групи комплексної терапії і у 12,50 \% у контролі, III ФК, відповідно, у 83,33 і 87,50 \%, p>0,05. Таким чином, за основними клініко-функціональними характеристиками хворі у групах втручання суттєво не різнились, що дозволило провести зіставлення ефективності методик лікування.

У процесі комплексної терапії усі дані моніторувались тричі: на стаціонарному етапі (1), під час візитів через 6-12 (2 візит) і через 18-24 місяці (3 візит).
На контрольному візиті через 6-12 місяців на фоні комплексної терапії з включенням оптимальних відтитрованих доз олмесартану і кверцетину стійкий синусовий ритм зберігався у 50,00 \% хворих з пароксизмальною формою фібриляції передсердь і у $38,46 \%$ - 3 персистуючою. У другій групі лише у $25,00 \%$, а через 18-24 місяці - тільки у $16,67 \%$, порівняно з третиною хворих у групі комплексної терапії $(\mathrm{p}<0,05)$. Тільки в контрольній групі до кінця спостереження у $11,10 \%$ спостерігали трансформацію фібриляції передсердь у постійну форму. Тривалість періоду стійкого синусового ритму у хворих 1 групи в середньому становила $(9,82 \pm 1,03)$ міс., в групі контролю $-(6,48 \pm 0,92)$ міс., $\mathrm{p}=0,045$.

Таким чином, на фоні комплексної терапії $з$ додатковим включенням ольмесартану і кверцетину в цілому в 1,7 раза частіше досягався кращий контроль ритму, триваліше (на $(3,34 \pm 0,97)$ місяця) утримувався стійкий синусовий ритм та не відбувалось прогресування фібриляції передсердь у перманентну форму упродовж двох років спостереження.

Таблиця 2. Динаміка морфометричних і масометричних показників серця під впливом комплексного лікування за даними парного t-тесту $(\mathrm{M} \pm \mathrm{m})$

\begin{tabular}{|c|c|c|c|c|}
\hline Показник & Термін спостереження & 1 група, $\mathrm{n}=28$ & 2 група, $\mathrm{n}=75$ & $\mathrm{p}_{1-2}$ \\
\hline \multirow[t]{3}{*}{ Ліве передсердя (ЛП), см } & стаціонар & $4,22 \pm 0,09$ & $4,49 \pm 0,09$ & 0,024 \\
\hline & 2 візит & $4,34 \pm 0,10$ & $4,51 \pm 0,11$ & нд \\
\hline & 3 візит & $4,02 \pm 0,09^{1,2}$ & $4,47 \pm 0,09$ & 0,001 \\
\hline \multirow{3}{*}{$\begin{array}{l}\text { Кінцевий систолічний розмір } \\
\text { (КСР), см }\end{array}$} & стаціонар & $4,15 \pm 0,11$ & $3,78 \pm 0,10$ & 0,024 \\
\hline & 2 візит & $4,06 \pm 0,12$ & $3,67 \pm 0,11$ & 0,028 \\
\hline & 3 візит & $3,98 \pm 0,12$ & $4,02 \pm 0,13^{2}$ & нд \\
\hline \multirow{3}{*}{$\begin{array}{l}\text { Кінцевий діастолічний розмір } \\
\text { (КДР), см }\end{array}$} & стаціонар & $5,77 \pm 0,10$ & $5,56 \pm 0,12$ & нд \\
\hline & 2 візит & $5,74 \pm 0,11$ & $5,58 \pm 0,12$ & нд \\
\hline & 3 візит & $5,75 \pm 0,13$ & $5,62 \pm 0,13$ & нд \\
\hline \multirow[t]{3}{*}{ Правий шлуночок (ПШ), см } & стаціонар & $2,84 \pm 0,08$ & $2,86 \pm 0,10$ & нд \\
\hline & 2 візит & $2,90 \pm 0,09$ & $3,01 \pm 0,11$ & нд \\
\hline & 3 візит & $2,70 \pm 0,07$ & $2,88 \pm 0,11$ & нд \\
\hline \multirow{3}{*}{$\begin{array}{l}\text { Міжшлуночкова перегородка } \\
\text { (МШП), см }\end{array}$} & стаціонар & $1,08 \pm 0,07$ & $1,09 \pm 0,06$ & нд \\
\hline & 2 візит & $1,09 \pm 0,08$ & $1,12 \pm 0,07$ & нд \\
\hline & 3 візит & $1,13 \pm 0,07$ & $1,25 \pm 0,07^{1}$ & нд \\
\hline \multirow{3}{*}{$\begin{array}{l}\text { Задня стінка лівого шлуночка } \\
\text { (ЗСлш), см }\end{array}$} & стаціонар & $1,05 \pm 0,03$ & $1,06 \pm 0,05$ & нд \\
\hline & 2 візит & $1,07 \pm 0,04$ & $1,18 \pm 0,06$ & нд \\
\hline & 3 візит & $1,08 \pm 0,04$ & $1,27 \pm 0,06^{1}$ & 0,018 \\
\hline \multirow{3}{*}{$\begin{array}{l}\text { Передсердно-шлуночкове } \\
\text { відношення (ПШВ), од }\end{array}$} & стаціонар & $0,73 \pm 0,04$ & $0,81 \pm 0,03$ & 0,048 \\
\hline & 2 візит & $0,76 \pm 0,04$ & $0,81 \pm 0,03$ & нд \\
\hline & 3 візит & $0,72 \pm 0,03$ & $0,79 \pm 0,02$ & 0,018 \\
\hline \multirow{3}{*}{$\begin{array}{l}\text { Відносна товщина стінок (ВТС), } \\
\text { ум.од }\end{array}$} & стаціонар & $0,38 \pm 0,02$ & $0,37 \pm 0,02$ & нд \\
\hline & 2 візит & $0,38 \pm 0,01$ & $0,42 \pm 0,02^{1}$ & 0,028 \\
\hline & 3 візит & $0,39 \pm 0,03$ & $0,41 \pm 0,01$ & нд \\
\hline \multirow{3}{*}{$\begin{array}{l}\text { Індекс маси міокарда лівого } \\
\text { шлуночка (ІММлш), г/м² }\end{array}$} & стаціонар & $127,17 \pm 8,30$ & $127,30 \pm 12,50$ & нд \\
\hline & 2 візит & $130,64 \pm 6,89$ & $149,53 \pm 15,48$ & нд \\
\hline & 3 візит & $135,87 \pm 7,11$ & $162,24 \pm 13,79^{1}$ & 0,048 \\
\hline
\end{tabular}

Примітки: 1$)^{1,2}$ - різниця у порівнянні із вихідними і повторним дослідженнями достовірна; 2) $\mathrm{p}_{1-2}$-достовірність різниці між $1 \mathrm{i}$ 2 групами; нд - різниця недостовірна. 
Динаміка показників морфофункціонального стану міокарда представлена у таблиці 2.

Як видно з таблиці 2, у групі комплексного лікування до кінця терміну спостереження (через 18-24 місяці) достовірно зменшились розміри лівого передсердя, у групі стандартної терапії зберігалась атріомегалія. При цьому в обох групах хворих передсердно-шлуночкове відношення в динаміці суттєво не змінювалось, однак до завершення спостереження спостерігалась достовірна позитивна різниця даного показника у порівнянні з другою групою, що підтверджує факт регресу атріомегалії у першій групі. Власне, на перший погляд, відсутність динаміки передсердно-шлуночкового відношення зумовлена відносним паралелізмом змін розмірів лівих камер серця, тільки в обох групах цей процес мав протилежний характер. Зокрема, кінцевий систолічний розмір у хворих першої групи несуттєво зменшувався, ау хворих другої групи достовірно збільшився, що також свідчить про поступове погіршення в динаміці систолічної функції в останніх.

Також чітко простежується прогресування гіпер-

\section{Література}

1. Діагностика та лікування фібриляції передсердь. Рекомендації робочої групи по порушеннях серцевого ритму Асоціації кардіологів України. - Київ, 2011.-156 с.

2. Дзяк Г. В. Фибрилляция предсердий / Г. В. Дзяк // Здоров'я України. - 2009. - Темат. номер (Вересень). - С. 15-16.

3. Нарушения ритма сердца : специалисты делятся опытом / [подгот. Д. Молчанов] // Здоров'я України. - 2006. № 4. - С. 24-25.

4. Сычев О. С. Руководство Европейского общества кардиологов (ESC) по ведению пациентов с фибрилляцией предсердий / О. С. Сычов // Therapia. -2007.-№ 2.-C. 5-12. трофіїлівого шлуночка у пацієнтів другої групи: достовірне потовщення стінок міокардаз суттєвим збільшенням індексу маси міокарда $(\mathrm{p}=0,048)$. Дана динаміка може свідчити про гірший контроль артеріальної гіпертензії в групі стандартної терапії і $є$ одним із вагомих несприятливих проаритмогенних чинників.

Висновок. Включення в комплексну терапію ФП олмесартану та кверцетину супроводжувалось достовірним покращенням показників гемодинаміки, що підтверджено результатами клінічного спостереження, динамічної оцінки добового моніторування АТ та морфофункціональних характеристик серця за даними ехокардіоскопії, що сприяло кращій стабілізації ритму: частіше досягався оптимальний контроль ритму, триваліше утримувався стійкий синусовий ритм та не відбувалось прогресування ФП у перманентну форму упродовж двох років спостереження. Таким чином, використання новітніх стратегій лікування ФП слід активно упроваджувати в клінічну практику. Одним із основних чинників реалізації даної проблеми повинна стати безперервна післядипломна освіта лікарів.

5. Маслій С. М. Динаміка клініко-лабораторних і морфофункціональних показників серця у хворих на різні форми фібриляції передсердь в динаміці спостереження при рутинному застосуванні стандартних клінічних протоколів лікування / С. М. Маслій // Здобутки клінічної і експериментальної медицини. -2012. - № 1. - С. $91-95$.

6. Пархоменко А. Н. Новые возможности в лечении больных с острым инфарктом миокарда с элевацией сегмента ST : корвитин для инъекций / А. Н. Пархоменко, С. Н. Кожухов // Український медичний часопис. - 2004. - № 2. - С. 33 -37 . 